\title{
MODEL PENILAIAN HASIL BELAJAR DAN KARAKTER
}

\author{
Heryanto \\ Universitas Mulawarman Samarinda \\ heryfe@yahoo.co.id
}

\begin{abstract}
Abstrak
Tujuan artikel ini adalah untuk memberikan gambaran komprehensif tentang penilaian hasil belajar dan penilaian karakter siswa. Penilaian hasil belajar siswa selama ini lebih terfokus pada penguasaan materi, tetapi kurang memperhatikan aspek karakter. Padahal dalam pendidikan memiliki dua dimensi tujuan, yaitu untuk menjadi cerdas dan berakhlah baik. Cerdas berkaitan dengan kognitif, sedangkan karakter berkaitan dengan afektif. Melalui kajian ini diharapkan diperoleh model penilaian yang melibatkan aspek kognitif dan afektif secara terpadu. Metode studi yang dilakukan dalam menyusun artikel melalui studi pustaka, yaitu mempelajari teori atau pendapat yang berhubungan dengan penilaian hasil belajar siswa. Berdasarkan kajian ini diperoleh gambaran sebagai berikut: (1) penilaian pembelajaran materi dan karakter dilakukan secara sendirisendiri; (2) guru mengalami kendala dalam menilai karakter siswa; (3) terdapat sejumlah intervensi terhadap guru dalam melakukan penilaian; (4) kolaborasi penilaian hasil belajar dan karakter sangat memudahkan guru, sekolah membuat keputusan yang bisa dipertanggungjawabkan; (5) penilaian hasil belajar memiliki implikasi yang positif terhadap pembentukan karakter siswa secara timbal balik.
\end{abstract}

\section{Kata kunci: guru, karakter, penilaian, siswa}

\begin{abstract}
The purpose of this article is to provide an overview of student learning and character assessment. The assessment of student learning has been focus more on mastery of material, but less attention to aspects of character. Whereas in education has two dimensions of purpose, namely to be smart and good morals. Intelligence has related to cognitive, while character has related to affective. Through this study, has expected to obtain a model of assessment that involves cognitive and affective aspects in an integrated manner. The method of study has done in compiling the article through literature study, i.e. studying the theory or opinion relating to student learning assessment. Based on this study, it concluded that: (1) Assessment of learning and character carried out independently. (2) Teachers face constraints assessing the character of students. (3) There are a number of interventions to the teacher's assessment; (4) Collaborative assessment of learning and character makes it easier for teachers and schools to make responsible decisions. (5) Assessment of learning has a positive implication on the formation of student character or otherwise.
\end{abstract}

Keywords: teacher, characters, assessments, students 


\section{A. PENDAHULUAN}

Akhir-akhir ini banyak dirasakan bahwa penilaian hasil belajar siswa tidak memberikan gambaran yang sebenarnya. Meskipun tidak seluruhnya, terdapat di beberapa sekolah yang meng-upgrade nilai untuk kepentingan tertentu. Di level SMA atau sederajat untuk kepentingan kelulusan 100\% dan atau seleksi masuk perguruan tinggi. Di level SMP atau sederajat untuk kepentingan memudahkan masuk dalam pendaftaran siswa baru ke SMA atau sederajat. Demikian juga pada tingkat sekolah dasar untuk kepentingkan masuk SMP atau yang sederajat. Adanya permintaan meng-upgrade bisa dilakukan oleh orang tua atau pihak sekolah. Hal inilah yang sering menjadi peran guru dalam melakukan penilaian yang seharusnya obyektif, terintervensi oleh pihak lain, sehingga guru tidak berfungsi sebagai penilai secara optimal. Fenomena ini sangat terlihat jelas pada sekelompok siswa yang tidak termotivasi untuk belajar, karena dalam pikiran mereka tidak belajar pun pasti naik kelas, tidak belajar pun pasti lulus. Inilah yang menjadi awal para guru sebagai pendidik tidak dihargai profesinya oleh siswa atau orang tua. Harus diakui ada hak-hak guru sebagai penilai yang terrampas, sehingga tak mengherankan jika ada guru ditimpas oleh siswanya. Tujuan pendidikan pada dasarnya bertujuan untuk membentuk individu menjadi cerdas (pintar) dan baik. Menjadi orang yang berpikiran cerdas dan berkarakter baik merupakan cita-cita mulia penyelenggaraan pendidikan.

Kaimuddin (2014) mengatakan, melalui pendidikan, potensi manusia akan tumbuh berkembang menjadi insan yang tertata pola pikirnya, termanifestasikan sikap dan tingkah laku baiknya. Pendidikan mengarahkan manusia dari sebelumnya tidak mengetahui banyak hal menjadi tahu banyak, sebelumnya berperilaku kurang baik menjadi berperilaku baik. Pendidikan menfasilitasi manusia menjadi dewasa, bertanggungjawab, jujur, beradab, dan berkarakter. Adanya gejala sikap masyarakat yang akhir-akhir ini dirasakan adalah pudarnya nilai-nilai luhur, terutama pada anak remaja sebagai penerus bangsa, sehingga memunculkan perilaku penyimpangan sosial yang tidak terpuji. Oleh karena itu, pendidikan menurut Marzuki (2018) harus mampu menjadi agent of change yang melakukan perbaikan karakter bangsa. Fungsi lembaga pendidikan, selain sebagai agen perubahan juga harus memiliki kemampuan menjadi agen seleksi (selection 
agent). Terjadinya kelunturan sopan santun di kalangan siswa kepada guru, orang tua, masyarakat diakibatkan kurang berfungsinya lembaga pendidikan. Dengan demikian, untuk membangun karakter mulia pada siswa maka seluruh komponen yang terlibat dalam penyelenggaraan pendidikan harus berfungsi sebagaimana mestinya. Guru memiliki peran yang utama dalam menentukan kebehasilan pendidikan melalui kegiatan belajar mengajar yang dilakukannya.

Mengingat guru memiliki peran yang demikian penting dalam pendidikan, maka untuk menjadi guru diperlukan kompetensi yang memadai. Ada beberapa kompetensi sebagai persyaratan menjadi guru. Dalam Stanford Teacher Competence Appraisal Guide yang dikutif Poerwanti (2015), menyebutkan ada empat kelompok kemampuan mengajar yaitu (1) kelompok kemampuan merencanakan pengajaran, (2) kelompok kemampuan penampilan mengajar, (3) kemampuan mengevaluasi hasil belajar, dan (4) kemampuan profesionalitas dan kemasyarakatan. Guru dalam kedudukannya sebagai pendidik, tentu memiliki tanggung jawab yang bersifat moral dan formal. Tanggung jawab moral adalah pertanggungjawaban kepada Tuhan Yang Maha Esa, sedangkan formal merupakan tanggung jawab kepada lembaga pemberi tugas, yaitu pemerintah.

Selanjutnya muncul pertanyaan mendasar apakah guru telah berperan sesuai tugasnya sebagai pendidik? Jawaban terhadap pertanyaan ini, ternyata tidak sepenuhnya peran guru sebagai pendidik berjalan secara optimal. Terdapat kendala yang harus dihadapi guru dalam melaksanakan tugasnya di lembaga pendidikan persekolahan. Kendala tersebut ada yang muncul karena bersifat internal dan eksternal. Kendala yang bersifat internal ialah hambatan yang disebabkan oleh faktor yang melekat pada guru yang bersangkutan, sedangkan eksternal berasal dari luar yang menjadi penghambat. Kendala yang bersifat internal biasanya bisa diatasi melalui peningkatan kemampuan dan keterampilan guru. Seiring dengan berjalannya waktu, guru dapat menambah pengalamannya sebagai pendidik. Mengikuti pendidikan lanjutan dan pelatihan merupakan upaya mengatasi hambatan internal. Akan tetapi, kendala atau hambatan yang bersifat eksternal sering menjadi bumerang bagi guru, sehingga sulit menghindarinya. Kebijakan naik atau lulus 100\% merupakan bentuk intervensi eksternal terhadap guru. Keadaan ini terlihat jelas dari sebagian sikap siswa yang tidak menghargai 
guru dalam proses kenaikan kelas atau kelulusan. Sekelompok siswa bersikap tak ada yang perlu dikhawatirkan, belajar atau tidak belajar pasti naik kelas atau lulus. Fenomena seperti ini nampaknya telah menjadi culture sekolah. Kondisi ini diperparah oleh rasa bangga sekolah yang menghasilkan kelulusan 100\% dengan mengorbankan hak-hak guru. Panitia seleksi masuk perguruan tinggi pernah menjatuhkan sanksi kepada sekolah yang diduga memanipulasi nilai siswanya.

Atas fenomena ini, maka dipandang perlu untuk mengembalikan hak-hak guru sesuai dengan tugas dan perannya. Guru tidak hanya dipandang sebagai orang yang memiliki legalitas dalam kelulusan siswa, tetapi juga telah berperan sebagai pendidik sebagaimana diamanat oleh undang-undang. Guru hendaknya diberikan kebebasan untuk mengekspresikan tugasnya dalam mendidik siswa. Peran guru harus benar-benar bebas dari intervensi dalam kegiatan penilaian hasil belajar siswa. Kegiatan penilaian terhadap hasil belajar siswa merupakan bagian yang tak terpisahkan dari seluruh rangkaian proses pembelajaran di berbagai tingkatan sekolah, termasuk sekolah dasar. Pemikiran yang mendasari perlunya melakukan penilaian bebas intervensi adalah untuk menekan hasil kesimpulan yang bias terhadap hasil belajar. Output nilai dari menggambarkan kondisi siswa yang sebenarnya. Menurut Arifin (2012) bahwa evaluasi merupakan salah komponen penting dan tahap yang harus ditempuh oleh guru untuk mengetahui keefektifan pembelajaran. Hasil yang diperoleh dapat dijadikan balikan (feedback) bagi guru dalam memperbaiki dan menyempurnakan program dan kegiatan pembelajaran.

Mengingat penilaian merupakan kegiatan yang memiliki banyak fungsi, maka untuk membangun karakter siswa dapat dilakukan melalui peran guru sebagai penilai karakter. Setidaknya aspek kegiatan penilaian akan memberikan informasi yang bermanfaat kepada guru, orang tua, sekolah dan paling utama siswa. Dari aspek penilaian inilah siswa akan mengetahui kondisi obyektif diri yang sebenarnya, siswa akan mengetahui kondisi intelektualnya dan juga karakternya. Atas dasar itu, kajian ini diharapkan dapat memberikan sebuah model yang mampu meningkatkan kualitas pendidikan. Bagaimana implementasi kegiatan penilaian yang dilakukan guru dapat memberikan implikasi positif secara timbal balik terhadap prestasi belajar dan pembentukan karakter akhlak mulia, 
sehingga dapat menghindari kegagalan dalam pendidikan. Kegagalan pendidikan dapat menciptakan produk yang tidak lagi memiliki kepekaan hati nurani yang berlandaskan moralitas, sense of humanity, dan problem kemerosotan moral (Nahdi, 2017).

\section{B. METODE}

Sesuai dengan tujuan penulisan artikel ini memadukan penilaian hasil belajar yang memuat aspek kognitif, afektif dan psikomotor, sehingga keputusan yang dibuat oleh guru atau sekolah bersifat komprehensif dan integratif. Berkenaan dengan tujuan tersebut, pendekatan yang digunakan dalam penulisan artikel ialah studi kepustakaan atau library research method, yaitu jenis studi yang dilakukan melalui penelusuran pustaka. Pendekatan ini cukup relevan untuk menjawab pertanyaan dalam studi ini, bagaimana membuat model kolaborasi antara penilaian hasil belajar dan karakter? Disebut penelitian kepustakaan karena data atau bahan-bahan yang diperlukan dalam menyelesaikan penelitian tersebut berasal dari perpustakaan baik berupa buku, ensiklopedi, kamus, jurnal, dokumen, majalah dan lain sebagainya (Harahap, 2014). Studi pustaka ini masih relevan digunakan untuk mencapai tujuan research. Studi pustaka tidak memerlukan penelitian lapangan karena semua informasi data yang diperlukan diperoleh melalui dokumen pustaka ilmuah. Pustaka ilmiah adalah semua tulisan yang ditulis berdasarkan hasil kegiatan ilmiah berupa penelitian ilmiah dengan menggunakan berbagai metode penelitian yang sahih dan didukung data yang reliabel dan valid serta dipublikasikan dalam berbagai bentuk terbitan dan atau dibicarakan dalam pertemuan ilmiah (Wahyuni, 2011). Dengan demikian, tegasnya riset pustaka membatasi kegiatannya hanya pada bahan-bahan koleksi perpustakaan saja tanpa memerlukan riset lapangan (Zed, 2008 dalam Khatibah, 2011). Walaupun disebut studi pustaka ilmiah, tidak semua pustaka dapat dijadikan rujukan tetapi setidaknya ada dua kriteria yang biasa digunakan untuk memilih sumber bacaan yaitu (a) prinsip kemutakhiran (recency) dan (b) prinsip relevansi (relevance) (Suryabrata, 1995). Oleh karena itu, jenis putaka dalam artikel ini terbatas pada pustaka yang dapat dikutif dan diringkas. Menurut Wahyuni (2011), jenis pustaka ilmiah yang dapat diringkas adalah: (1) buku-buku 
yang ditulis berdasarkan hasil penelitian atau pemikiran ilmiah, (2) artikel jurnal ilmiah, (3) tesis, dan (4) makalah ilmiah yang telah dipresentasikan dalam pertemuan ilmiah yang telah dibukukan dalam prosiding.

\section{HASIL DAN PEMBAHASAN}

\section{Pengertian Penilaian}

Menurut Arifin (2012), istilah penilaian merupakan alih bahasa dari istilah assessment, bukan dari istilah evaluation. Dalam proses pembelajaran, penilaian sering dilakukan guru untuk memberikan berbagai informasi secara berkesinambungan dan menyeluruh tentang proses dan hasil yang telah dicapai peserta didik. Di tingkat sekolah dasar dan menengah, kegiatan penilaian dilakukan oleh guru. Penilaian tidak terbatas pada penguasaan pengetahuan satu bidang mata pelajaran yang menjadi tanggung jawabnya, tetapi terintegrasi dengan aspek lainnya seperti ketempilan dan sikap kepribadian siswa. Hal ini sejalan dengan fungsi pendidikan sebagai lembaga yang mendidik siswanya menjadi pintar atau cerdas dan juga baik. Kata kunci pintar dan baik harus menjadi landasan acuan penyelenggaraan pendidikan. Oleh karena itu, penilaian guru terhadap hasil belajar siswa harus komprehensif yang menggambarkan kemampuan intelektualnya juga sikap, dan perilaku akhlaknya.

Dalam kegiatan asesmen, ada tiga kegiatan yang selalu dilakukan guru, yaitu tes, pengukuran, dan evaluasi. Istilah-istilah itu yang sering dipertukarkan dengan maksud yang sama, padahal masing-masing mempunyai arti dan tujuan yang berbeda. Untuk menghindari kekeliruan dalam menafsirka istilah tersebut, Kizlik (2012) menyatakan:

Test is a method to determine a student's ability to complete certain tasks or demonstrate mastery of a skill or knowledge of content. Some types would be multiple-choice test, or a weekly spelling test. While it commonly used interchangeably with assessment, or even evaluation, it can distinguished by the fact that a test is one form of an assessment.

Assessment is the process gathering information to monitor progress and make educational decisions if necessary. As noted in my definition of test, 
an assessment may include a test, but also includes methods such as observations, interviews, behavior monitoring, etc.

Evaluation is procedures used to determine whether the subject (i.e. student) meets a preset criterion, such as qualifying for special education services. This uses assessment (remember that an assessment may be a test) to make a determination of qualification in accordance with a predetermined criteria.

Measurement, beyond its general definition, refers to the set of procedures and the principles for how to use the procedures in educational tests and assessments. Some of the basic principles of measurement in educational evaluations would be raw scores, percentile ranks, derived scores, standard scores, etc.

Berdasarkan kutifan tersebut di atas secara jelas bahwa dalam penilaian memerlukan tes, pengukuran, dan evaluasi. Untuk melihat kedudukan tes, pengukuran dan evaluasi lihat Gambar 1 berikut ini.

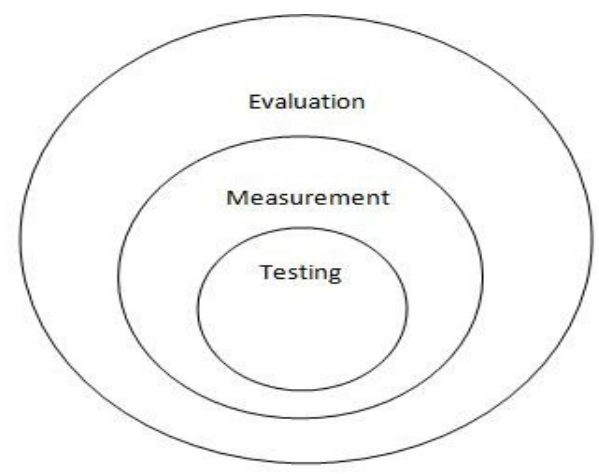

Sumber: Alternatives in Assessment (Bastanfar, 2012)'

\section{Gambar 1. Kedudukan tes, Pengukuran dan Penilaian}

In the most general sense, assessment is the process of making a judgment or measurement of worth of an entity (e.g., person, process, or program). Educational assessment involves gathering and evaluating data evolving from planned learning activities or programs (Scanlan, 2012). Selanjutnya Arifin (2012), mengatakan hubungannya dengan proses dan hasil belajar, penilaian dapat didefinisikan sebagai suatu proses atau kegiatan yang sistematis dan berkesinambungan untuk mengumpulkan informasi tentang proses dan hasil 
belajar peserta didik dalam rangka membuat keputusan-keputusan berdasarkan kriteria dan pertimbangan tertentu.

\section{Tujuan dan Mantaat Penilaian}

Penilaian hasil belajar siswa memiliki tujuan yang bermanfaat untuk guru, siswa, sekolah, dan pihak pembuat kebijakan yang terkait dengan pendidikan. Menurut Brissenden and Slater yang dikutif Scanlan (2012), state that learner assessment represents a particular type of educational assessment normally conducted by teachers and designed to serve several related purpose. Include (a) motivating and directing learning, (b) providing feedback to student on their performance,(c) providing feedback on instruction and/or the curriculum, (d) ensuring standards of progression are met. Hal lain yang tidak kalah pentingnya adalah penilaian harus dipahami dan dianggap sebagai bentuk komunikasi dua arah antara guru dan siswanya. Sebagaimana diungkapkan oleh McAlpine (2002), that the learner assessment conceived as a form of two-way communication in which feedback on the educational process or product provided to its key stakeholders. Komunikasi bagi guru terkait dengan pengajaran sebagai umpan balik, sedangkan bagi siswa terkait umpan balik belajar. Tidak hanya itu saja, penilaian hasil belajar juga bermanfaat untuk pengembangan kurikulum, sumber daya manusia penyelenggara dan pengguna pendidikan.

Dalam studi ini, penulis membatasi manfaat penilaian siswa berdasarkan aspek guru yang melalukan kegiatan mengajar dan siswa melakukan kegiatan belajar. Menurut Brissenden and Slater sebagaimana dikutif Scanlan (2012), classroom assessment can help teachers answer the following specific questions: (a) to what extent are my students achieving the stated goals? (b) How should I allocate class time for the current topic? (c) Can I teach this topic in a more efficient or effective way? (d) What parts of this course/unit are my students finding most valuable? Seluruh jawaban atas pertanyaan yang diajukan tersebut akan memberikan ruang yang luas kepada guru untuk melakukan berbagia tindakan sebagaimana mestinya. Kegiatan mengajar bukanlah aktivitas yang pasif tetapi penuh dinamika yang unik. Setiap mengajar, guru akan menghadapi situasi dan kondisi yang berbeda, baik dari aspek tujuan, materi yang disajikan maupun siswanya. Pada umumnya, seorang guru mengajar lebih dari satu kelas, sehingga 
akan menghadapi siswa yang berbeda setiap kelasnya. Tidak akan pernah ada peristiwa yang persis sama antara satu kegiatan belajar mengajar dengan yang lainnya. Hal ini sesuai dengan karakteristik interaksi sosial yang syarat dengan kontekstual.

Bermanfaat bagi siswa jika menjawab serangkaian pertanyaan sebagai berikut: (a) Do I know what my instructor thinks is most important. (b) Am I mastering the course content?; (c) How can I improve the way I study in this course? (d) What grade am I earning in this course? (Brissenden dan Slater dalam Scanlan, 2012), Sama halnya dengan pertanyaan guru bahwa jawaban atas pertanyaan siswa akan mendorong pemahaman dan kebermaknaan guru dengan segala aktivitasnya dalam mengajar. Dengan demikian, pelaksanaan penilaian mempunyai dua sasaran sekaligus, yaitu yang bersifat makro dan mikro. Bersifat makro sasarannya adalah program pendidikan, yaitu program yang direncanakan untuk memperbaiki bidang pendidikan, sedangkan mikro sering digunakan di tingkat kelas, khususnya untuk mengetahui pencapaian belajar peserta didik (Darsono, 2013). Dalam kajian ini, menekan pada mikro yaitu program pembelajaran di kelas dan yang menjadi penanggungjawabnya adalah guru untuk sekolah atau dosen untuk perguruan tinggi (Mardapi, 2000 dalam Darsono, 2013).

\section{Penilaian Karakter}

Sebagaimana telah disinggung di awal, bahwa karakter berkaitan perilaku moral yang dipakai dalam kehidupan sehari-hari. Menurut Easley (2002) bahwa karakter berkaitan dengan keteguhan hati, ketekunan, rasa hormat, tanggung jawab, dan disiplin diri. Bahasan tentang karakter telah banyak dikupas, mulai dari yang sederhana sampai yang kompleks. Sesuai dengan tujuan pendidikan yaitu membentuk manusia yang cerdas dan baik, maka penilaian terhadap karakter siswa menjadi tak kalah pentingnya dengan penilaian kecerdasan. Menurut Mardapi (2017) karakter berkaitan dengan personalitas walaupun ada perbedaannya. Personalitas merupakan trait bawaan sejak lahir, sedang karakter merupakan perilaku hasil pembelajaran. Di lingkungan pendidikan terutama persekolahan, karakter sering dihubungkan dengan pendidikan karakter untuk menilai seberapa baik kualitas siswa yang dididiknya dalam berperilaku. 
Selanjutnya menurut Lickona (2004) yang dikutif Sobri (2015), bahwa karakter adalah sesuatu yang terlihat. Karakter terdiri dari sifat baik sebagai bentuk dari perilaku yang sesuai moral, sehingga karakter merupakan bentuk perilaku konkrit, atau penerapan dari moral. Sebenarnya persoalan pendidikan karakter telah disadari sejak tahun 1947 atau dua tahun setelah kemerdekaan, namun belum memberikan hasil yang diharapkan. Karakter yang dimiliki seseorang berada pada domain atau ranah afektif. Menurut Andersen (1980) yang dikutif Mardapi (2017) ada dua metode yang dapat digunakan untuk mengukur ranah afektif, yaitu metode observasi dan metode laporan-diri. Penggunaan metode observasi berdasarkan pada asumsi bahwa karateristik afektif dapat dilihat dari perilaku atau perbuatan yang ditampilkan, reaksi psikologi, atau keduanya. Metode laporan-diri berasumsi bahwa yang mengetahui keadaan afektif seseorang adalah dirinya sendiri. Namun, hal ini menuntut kejujuran dalam mengungkap karakteristik afektif diri sendiri.

Pada dasarnya karakter siswa dapat dinilai oleh guru, baik secara kualitatif maupun kuantitatif. Ada beberapa langkah harus dilakukan guru untuk menilai pendidikan karakter, sebagaimana diungkapkan oleh Sutijan (2015), dalam pengembangan instrument untuk penilaian pendidikan karakter harus mengikuti langkah-langkah pengembangan instrument afektif sebagai berikut: (1) menentukan spesifikasi instrument; (2) menulis instrument; (3) menentukan skala instrument; (4) menentukan system penskoran; (5) menelaah instrument; (6) melakukan ujicoba; (7) menganalisis instrument; (8) merakit instrument, (9) melaksanakan pengukuran; dan (10) menafsirkan hasil pengukuran.

\section{Implementasi Penilaian Dalam Membangun Karakter}

Melalui pendekatan penyederhanaan diasumsikan jika siswa di sekolah manapun dibagi dalam dua kategori tujuan pendidikan, yaitu menjadi baik dan cerdas (pintar) maka terdapat empat kelompok utama sebagaimana disajikan dalam Gambar 1 berikut ini. Kelompok siswa pertama ada di kuadran 1, yaitu siswa yang selain cerdas juga baik karakternya. Kelompok siswa kedua, yaitu siswa yang kurang cerdas tetapi berkarakter baik. Kelompok siswa ketiga, yaitu siswa yang cerdas tetapi berkarakter kurang baik, sedangkan kelompok siswa keempat adalah siswa yang selain kurang pintar juga berkarakter kurang baik. 
Penanganan masing-masing kelompok, sudah barang tentu berbeda karena setiap kelompok memiliki kebutuhan layanan pendidikan yang berbeda. Melalui pemetaan seperti ini akan memudahkan para pihak, seperti guru, siswa, orang tua, dan pihak sekolah mengambil kebijakan dalam proses pendidikan.

Pembinaan kelompok siswa yang cerdas dan berkarakter baik adalah memberikan penguatan melalui reward yang dapat memotivasi untuk mempertahan dan meningkatkan prestasinya. Layanan pada kelompok 2 yaitu siswa yang berkarakter baik namun kurang cerdas adalah memberikan dorongan untuk belajar sehingga mencapai tingkat kecerdasan yang diinginkan. Biasa pada kelompok bisa diberikan belajar tambahan atau bentuk-bentuk lain seperti tugastugas tambahan. Berbeda dengan kelompok 3, yaitu siswa yang cerdas tetapi berkarakter kurang baik. Pembinaan pada siswa yang demikian diarahkan untuk memahami nilai-nilai kebaikan. Nilai kebaikan bisa dari sumber budaya masyarakat yang berlaku dan juga nilai-nilai dari agama yang dianutnya. Pembinaan terhadap siswa secara keseluruhan tidak dapat dilakukan oleh guru seorang diri, tetapi perlu berkolaborasi dengan pihak lain yang dianggap memiliki kepentingan, seperti siswa itu sendiri, teman sesama guru, pihak sekolah, dan orang tua siswa. Melalui kolaborasi ini akan terbangun sinergi yang mampu membangun kondisi yang positif, sehingga melahirkan siswa yang cerdas dan berkarakter baik. Dengan demikian, segala pontensi sumber daya pendidikan diarahkan pada kelompok siswa yang berada di kuadran 2, 3, 4 ke arah kuadran 1.

\begin{tabular}{|c|c|c|c|}
\hline & \multicolumn{2}{|c|}{ Kecerdasan intelektual } \\
\hline & & Cerdas & $\begin{array}{c}\text { Kurang } \\
\text { cerdas }\end{array}$ \\
\hline \multirow{2}{*}{ 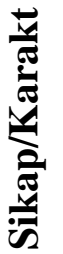 } & Baik & 1 & 2 \\
\hline & $\begin{array}{c}\text { Kurang } \\
\text { baik }\end{array}$ & 3 & 4 \\
\hline
\end{tabular}

\section{Gambar 1. Kelompok Siswa Berdasarkan 2 Kategori}

Selama ini sangat dirasakan kebijakan yang diambil oleh sekolah, bahkan pemerintah tidak bersinggungan dengan kepentingan pendidikan. Pada umumnya 
kebijakan sekolah menaikan atau meluluskan sebanyak-banyak hingga 100\% atas dasar alasan pencitraan semata atau alasan-alasan lain yang kurang dapat dipertanggungjawabkan. Inilah yang menjadi cikal bakal kelahiran generasi yang tidak memiliki karakter baik, dan saat ini sebagian telah dirasakan oleh masyarakat pada umumnya. Terlepas dari ada atau tidaknya intervensi dalam penilaian, namun guru perlu memberitahukan secara obyektif tentang kondisi masing-masing siswa. Bagaimanapun, asesmen atau penilaian memiliki peran yang penting dalam pendidikan.

Guru sebagai penilai memiliki banyak tuntutan yang harus terpenuhi, selain memiliki keterampilan dalam menyusun alat ukur, juga harus memahami kondisi kualitas dirinya. Guru yang baik adalah guru yang memahami keunggulan dan kekurangan pada dirinya. Pada beberapa sekolah, kualitas guru sering ditingkatkan melalui program observasi kelas. Melalui obervasi kelas ini diharapkan kualitas guru sebagai penilai meningkat. It is almost impossible that these days to find a teacher evaluation program in which classroom-observation evidence does not play a prominent role. This is true whether the thrust of a teacher-evaluation program is formative (directed toward improving a teacher's performance) or summative (related to an upcoming personnel decision about the teacher). Indeed, many people-including substantial numbers of educatorsregard classroom observations as being essentially equivalent to teacher evaluation (Popham, 2014).

Peraturan Menteri Pendidikan dan Kebudayaan Republik Indonesia Nomor: 23/2016 tentang standar penilaian pendidikan pasal 5, menyatakan prinsip penilaian hasil belajar adalah sahih, objektif, adil, terpadu, terbuka, menyeluruh dan berkesinambungan, sistematis, beracuan kriteria, dan akuntabel. Peraturan ini memberi indikasi terhadap peran penilaia menjadi fondasi penting dalam menghadapi tantangan global. Menurut Alvares dan Casares (1998), state that evaluation seeks to respond to the need for practical knowledge, the need to make decisions, and the need to reinvent particular objects or programs. However, the accumulation of the results of various evaluations begins to form a pillar of learning that inevitably transcends the immediate concerns of a given activity or program. Evaluation provides, in effect, an opportunity for the convergence of 
three dimensions: the utopias and ideals of a society, available knowledge, and social practice.

Penilaian yang diwujudkan dalam bentuk evaluasi tidak hanya memberikan fasilitas terhadap kebijakan dan praktik sesuau dengan tujuan yang diharapkan, tetapi juga membantu untuk memahami antara idealis dan hal yang dapat yang dapat dicapai. Ketiga dimensi ini harus nampak terwakili secara jelas pada setiap level tertentu pada setiap kegiatan evaluasi. Walaupun, evaluasi sering diperdebatkan secara berkepanjangan, namun karena ada pengaruh luar, maka evaluasi menjadi penuh dinamika yang bergantung pada waktu dan pengetahuan. Dalam banyak kasus, kegiatan evaluasi tidak terlepas dari ideologis, filosofis dan kehidupan politi. Penilaian kemajuan pribadi atau apapun, sangat tidak mungkin dipisahkan dari pengetahuan, nilai, dan utopia yang berbaur dalam proporsi yang berbeda seselama proses evaluasi berlangsung. Oleh karena itu dalam proses ini sangat memungkinkan seorang individu membandingkan dirinya dengan orang lain, dan dengan cita-citanya. Contoh, evaluasi guru dikolaborasikan dengan kriteria dari standar praktik profesional, hasil penelitian terkini, dan termasuk harapan masyarakat.

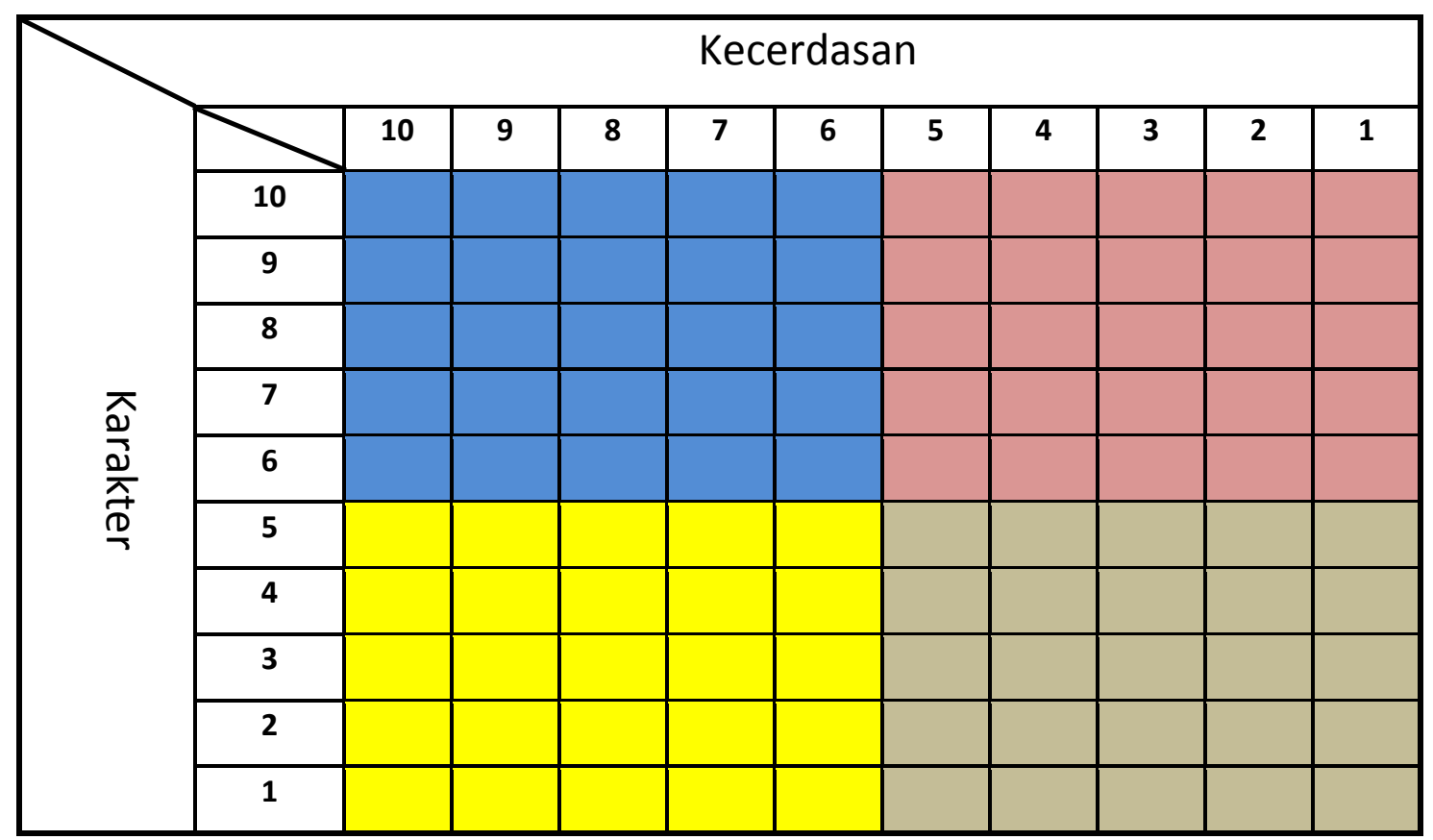

Gambar 2. Model Penilaian Hasil Belajar dan Karakter 
Dalam beberapa praktek sering muncul strategi pembentukan karakter siswa dengan cara-cara yang kurang dianjurkan, namun memberi dampak positif. Apakah karakter negatif guru dapat berimplikasi baik terhadap perkembangan prestasi siswa. Hal ini bisa terjadi, sebagaimana diungkapkan Popham (2014) the teacher has one or more negative personal characteristics-such tendency to use student-embarrassing sarcasm or a thick foreign accent? These negative characteristics might overwhelm the anticipated positive effects flowing from the teacher's research-sanctioned instruction.

Dalam praktek, karakteristik negatif ini bisa memberikan efek positif terhadap karakter siswa, namun sangat tidak dianjurkan karena sulit memprediksi siswa yang dapat meresponnya secara positif. Bahkan dikhawatirkan terjadi hal yang tidak diharapkan menjadi lebih buruk dari keadaan semula. Seorang guru memberikan hukuman kepada siswa dalam menidik sering disalahkanartikan sehingga menimbulkan salah paham, yang berujung terganggunya hubungan siswa dengan guru. Mengingat penilaian hasil belajar mengandung tiga domain, yaitu kognitif, afektif dan psikomotor maka keputusan terhadap hasil belajar siswa harus menyertakan hal tersebut. Contoh penilaian hasil belajar siswa berbasis pendidikan karakter, disajikan dalam Gambar 2. Pengukuran kecerdasan bisa dilakukan secara kuantitatif, sedangkan karakter secara kualitatif. Pada umumnya pengukuran karakter dilakukan melalui skala tertentu, apakah menggunakan skala Likert atau semantik. Banyak cara yang bisa dilakukan guru mengukur karakter siswa. Dalam Gambar 2, memperlihatkan contoh pengukuran dengan pendekatan semantik. Angka 1 (satu) menggambarkan karakter atau sikap yang buruk, sedangkan angka 10 menggambarkan karakter sangat baik. Tugas guru adalah membuat standar yang layak memperoleh kenaikan kelas atau kelulusan. Berdasarkan penilaian hasil belajar yang memadukan kecerdasan dan karakter, setidaknya hasil proses pendidikan lebih akurat dalam menggambarkan keadaan yang sebenarnya.

Dalam praktek tidak sedikit guru yang mengajar berbasis materi secara terfokus, sehingga kurang memperhatikan aspek karakter. Saefuddin (2012) mengungkapkan bahwa masih banyak guru yang mengajar hanya berorientasi pada materi atau bahan ajar, sehingga guru sering melakukan kesalahan dalam 
mengukur serta menilai hasil belajar dan kompetensi peserta didik. Untuk menghindaran penilaian yang bias karena sering disinonimkan dengan evaluasi, maka Scanlan (2012) menjelaskan berdasarkan beberapa dimensi sebagai berikut:

Tabel 1. Perbedaan Asesmen dengan Evaluasi

\begin{tabular}{|l|l|l|}
\hline \multicolumn{1}{|c|}{ Dimension } & \multicolumn{1}{c|}{ Assessment } & \multicolumn{1}{c|}{ Evaluation } \\
\hline Timing & Formative & Summative \\
\hline Focus of Measurement Administrator and & Reflective & Prescriptive \\
\hline $\begin{array}{l}\text { Relationship Between } \\
\text { Recipient }\end{array}$ & Diagnostic & Judgmental \\
\hline Findings and Uses & Flexible & Fixed \\
\hline Modifiability of Criteria, Measures & Absolute (Individual) & Comparative \\
\hline Standards of Measurement & Cooperative & Competitive \\
\hline Relation Between Objects of A/E & Process-Oriented & Product-Oriented \\
\hline
\end{tabular}

Sumber: Apple, D.K. \& Krumsieg. K.1998. Process education teaching institute handbook. Pacific Crest

Berdasar pada Tabel 1 di atas, adalah sangat tepat asesmen (penilaian) digunakan untuk tujuan membentuk karakter siswa. Setidaknya penilaian sebagai produk harus berbasiskan fakta data yang validitas dan reliabilitasnya bisa dipertanggungjawabkan. Sebagaimana disarankan oleh Lynch (2001), we have to notice the fact that all alternatives in assessment have to meet their respective requirements for reliability and validity to make teachers able to come to sound judgments. Maka dari itu diperlukan pendekatan penilaian yang mengitegrasikan berbagai dimensi, seperti tujuan, kurikulum atau lainnya yang berhubungan dengan perencanaan dan prosedur pengajaran dan pembelajaran. Hal ini diungkapkan oleh McNamara (2000) yang dikutif oleh Bastanfar (2012), this approach stresses the need for assessment to be integrated with the goals of the curriculum and to have a constructive relationship with teaching and learning.

\section{SIMPULAN}

Penilaian yang dilakukan oleh guru sekolah selama ini lebih banyak menekan pada aspek pembelajaran materi yang berbasis kurikulum, sedangkan aspek pembelajaran karakter kurang optimal. Hal ini menjadi salah satu sebab munculnya generasi (lulusan) yang cerdas tetapi tidak berkarakater. Selain itu, 
intervensi pihak lain terhadap guru dalam tugasnya memperparah kondisi lulusan. Tidak sedikit siswa yang memperoleh sertifikat kelulusan atau ijazah dengan kualifikasi kurang cerdas dan juga kurang berkarakter. Melalui sinergi penilaian hasil pembelajaran mata pelajaran dan karakter diharapkan menghasilkan lulusan yang benar-benar cerdas dan berkarakter baik sehingga menjadi andalan sebagai penerus bangsa.

\section{DAFTAR PUSTAKA}

Alvarez, B. dan Casares (ed). 1998. Evaluation and Educational Reform: Policy option. U.S. Agency for International Development.

Apple, D.K. \& Krumsieg. K. 1998. Process Education Teaching Institute Handbook. Pacific Crest.

Arifin, Z. 2013. Evaluasi Pembelajaran: Prinsip, Teknik, Prosedur. Bandung: Remaja Rosdakarya.

Bastanfar, A. 2012. Alternatives in Assessment. Islamic Azad University, Khoy, Iran.

Darsono, Imam. 2013. Peran Guru Dalam Evaluasi Pembelajaran. SNEP I Tahun 2013:503-511.

Djemari, M. 2010. Penilaian Pendidikan Karakter, Bahan Tulisan Pendidikan Karakter Universitas Negeri Yogyakarta, http://staff.uny.ac.id/Sites/default/tmp/ Penilaian_karakter.pdf. (Diakses 1908-2017).

Easley, M.F. 2002. Character and Civic Education. Public Schools of North Carolina. Raleigh.

Harahap, Nursapi. 2014. Penelitian Keputakaan. Jurnal Iqra’ Volume 08 No.01 Mei, hlm 68-74.

Kaimuddin. 2014. Implementasi Pendidikan Karakter Dalam Kurikulum 2013. Jurnal Dinamika Ilmu Vol. 14. No 1, Juni 2014: 47-65.

Kizlik, B. 2012. Measurement, Assessment, and Evaluation in Education. http://www.adprima.com /measurement.htm (Diakses tanggal 02-03-2017).

Lynch, B.K. 2001. Rethinking Assessment from a Critical Perspective. Language Testing 18 (4), 2001: 351-372. 
Marzuki. 2018. Konsep Dasar Pendidikan Karakter. http://staff.uny.ac.id/sites/default/files/.../57-konsep-dasar-pendidikankarakter-marzuki.pdf. (Diakses tanggal 02-01-2018).

McAlpine, M. 2002. Principles of Assessment. Glasgow: University of Glasgow, Robert Clark Center for Technological Education.http://www.caacentre.ac.uk/dldocs/Bluepaper1.pdf. (Diakses tanggal 02-01-2018).

Nahdi, D.S. 2017. Membentuk Karakter Siswa Dengan Menanamkan Nilai-nilai Matematika. Naturalistic: Jurnal Kajian Penelitan Pendidikan dan Pembelajaran. Vol 2, No. 1, Oktober 2017: 1-7.

Poerwanti, $\quad$ Endang. 2015. Konsep Dasar Asesmen Pembelajaran. https://sites.google.com/site/ asesmenpembelajaran/unit-1. (Diakses tanggal 05-01-2018).

Popham, W.J. 2014. Classroom-Observation Evidence in Teacher Evaluation: Playing the Ponies. Los Angeles, University of California.

Saefuddin, A. 2012. Merancang Teknik Penilaian Berbasis Kelas. Jurnal IIP Volume. XVII No. 1 2012/1433: 47-65.

Scanlan, CL. 2012. Assessment, Evaluation, Testing and Grading. $\quad$ http://www.umdnj.edu/idsweb $\quad$ /idst5350 /assess_eval_test_grade.htm (Diakses tanggal 02-03-2017).

Sobri, AY. 2010. Menumbuhkan Nilai Karakter Siswa di sekolah. http://ap.fip.um.ac.id/wp-content/ uploads/2015/10/1-ahmad-yusufsobri.pdf.

Suryabrata, Sumadi. 1995. Metodologi Penelitian. Jakarta : Rajawali Pers.

Sutijan, Hasan Makhfud, Lies Lestari, dan Chumdari. 2015. Pengembangan instrumen penilaian pendidikan karakter terpada. Jurnal Paedagogia, Vol. 18 No. 2 Tahun 2015:1-9.

Wahyuni, E.S. 2011. Pedoman Teknik Penulisan Laporan Studi Pustaka. Mayor Sains Komunikasi dan Pengembangan Masyarakat Fakultas Ekologi Manusia IPB. Bogor: IPB.

Zed, Mestika. 2011. Metode Penelitian Kepustakaan, Jakarta: Yayasan Obor. 
